\title{
Optimasi Produksi Sumur CBM dengan Radial Jet Drilling (Rjd)
}

\author{
Rohima Sera Afifah ${ }^{1}$, Karmila ${ }^{1}$, Arief Adhiksana ${ }^{2}$, Andi Jumardi ${ }^{1}$, \\ ${ }^{1}$ Sekolah Tinggi Teknologi Migas Balikpapan \\ ${ }^{2}$ Politeknik Negeri Samarinda
}

Email: rohimasera.afifah@gmail.com

\begin{abstract}
To produce gas methane from the coal bed methane (CBM) field requires the right completion system that considers the reservoir properties which are encountered. One of technologies that is recommended to produce gas methane in the CBM field is Radial Jet Drilling System (RJD).Two important aspects which are considered to test the feasibility of RJD in the CBM field are the problems that usually show up while drilling and producing. The other aspects are the principle of RJD that considers several special tools like radial jetting and length of radial and the problems that usually present during RJD's application in conventional field like water blocking, hole positioning and hole cleaning.To see the effectiveness of RJD, a comparison with other completion systems (vertical well) is done through simulation step by using WS field data, precisely at BP formation. CBM field simulation that is produced with vertical well system is sensitive to the addition of wells. Meanwhile the CBM field that is produced by RJD completion has sensitivity tothe number of radial phases and the length of each phase.The results show that RJD can be applied in the CBM well with certain parameters then the RJD effectiveness can be achieved with the minimum number of three phases, where the distance of each phase is 90 degrees and length of each radial phase is 300 until $500 \mathrm{ft}$.
\end{abstract}

Key words: Completion, CBM, RJD, radial jetting, water blocking, hole cleaning, hole positioning, simulation, WS field

\begin{abstract}
Abstrak
Untuk memperoleh produksi gas metan pada lapangan CBM maka dibutuhkan sistem komplesi yang tepat dengan tetap mempertimbangkan karakteristik reservoir CBM yang dihadapi. Salah satu teknologi yang di rekomendasikan untuk memproduksi gas metan pada lapangan CBM adalah Radial Jet Drilling (RJD).Dua aspek penting yang dipertimbangkan untuk menguji kelaikan RJD pada lapangan CBM ialah masalah yang biasa muncul pada saat pemboran dan pada saat proses produksi. Aspek berikutnya adalah prinsip kerja RJD yang mempertimbangkan beberapa alat khusus seperti radial jetting dan panjang radial, serta masalah yang biasa muncul seiring dengan aplikasi RJD pada lapangan konvensional seperti water blocking, hole position dan hole cleaning.Sementara untuk melihat keefektifan RJD maka dilakukan perbandingan dengan sistem komplesi lain (sumur vertical) melalui tahap simulasi dengan menggunakan data lapangan WS tepatnya pada formasi BP. Simulasi lapangan CBM yang diproduksi dengan sistem sumur vertikal di sensitivitas dengan menambahkan sumur. Sedangkan lapangan CBM yang diproduksi dengan sistem komplesi RJD di sensitivitas terhadap jumlah fase radial dan panjang masing-masing fase.Hasil pengujian menunjukkan bahwa RJD dapat diaplikasikan pada sumur CBM dengan parameter tertentu sedangkan efektifitas RJD dapat dicapai pada jumlah fase minumum 3 (tiga), dengan jarak antara fase $90^{\circ}$ dan dengan panjang radial masing-masing fase $300 \mathrm{ft}-500 \mathrm{ft}$.
\end{abstract}

Kata kunci : Komplesi, CBM, RJD, radial jetting, water blocking, hole cleaning, hole position, simulasi, WS.

\section{Pendahuluan}

Pemerintah melalui program Energi Mix 2016-2025 berdasarkan Keputusan Presiden No.5 Tahun 2006 menargetkan pasokan gas sebesar $30 \%{ }^{9}$, dan mengandalkan potensi sumberdaya CBM yang diperkirakan mencapai $453 \mathrm{TCF}^{9}$ dari kelompok sumberdaya bukan konvensional bersama dengan shale gas, tight gas sand dan gas hidrat. 
Namun untuk memproduksikan suatu volume tertentu pada reservoir CBM, dibutuhkan jumlah sumur 10 kali lebih banyak dibanding pada reservoir gas konvensional $^{13}$

Disaat yang sama, teknologi pemboran untuk menghasilkan produksi hidrokarbon optimum juga terus berkembang diantaranya adalah Radial Jet Drilling(RJD), metoda pemboran eksisting yang dikenal sejak tahun 40-an namun terus berkembang sehingga mampu memperbesar produksi sumur $2 \mathrm{~s} / \mathrm{d}$ 10 kali lipat ${ }^{5}$

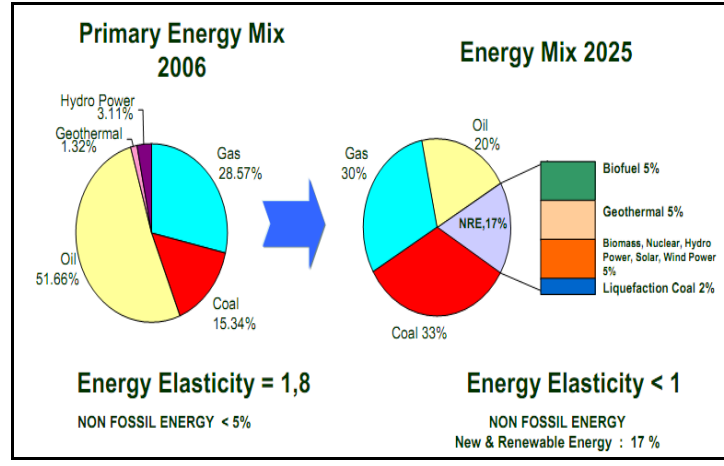

Gambar 1. Program Energi Mix Indonesia ${ }^{24}$.

\section{Metodologi Uji Kelaikan RJD untuk Sumur CBM}

Radial Jet Drilling (RJD) adalah teknologi pemboran dan komplesi yang dikenal sejak tahun 40 an dan semakin populer melalui beberapa paper pada tahun 80 an sebagai hasil dari aplikasi lapangan yang terbukti efektif dan hingga kini terus dikembangkan melalui penelitian. Optimasi yang dilakukan oleh RJD ialah dengan membuat lubang horizontal dari sumur vertikal dengan tujuan memperbesar laju produksi melalui "jalan" yang terbentuk berupa radius $4 \frac{1}{2}$ inch dan menempatkan tubing $1 \frac{1}{2}$ inch. Kondisi ini membuat fluida mengalir lebih mudah dari lapisan produktif menuju lubang sumur. Sejak tahun 1989 tercatat lebih dari $27,000 \mathrm{ft}(8,230 \mathrm{~m})$ sumur telah dibor dan lebih dari 500 radial horizontal yang dibuat dengan menggunakan RJD. RJD juga sering dikenal dengan istilah
Radial jet drilling, Water-Jet Drilling, dan Horizontal Radial System.

Hingga saat ini metoda RJD hanya dikenal pada lapangan konvensional oleh karena itu pada bab ini akan di terangkan metodologi studi kelaikan RJD untuk sumur CBM yang dibagi ke dalam 2 (dua) aspek besar iaitu berdasarkan prinsip kerja RJD dan berdasarkan CBM problem dengan skema yang dapat dilihat melalui diagram alur pada Gambar 2.

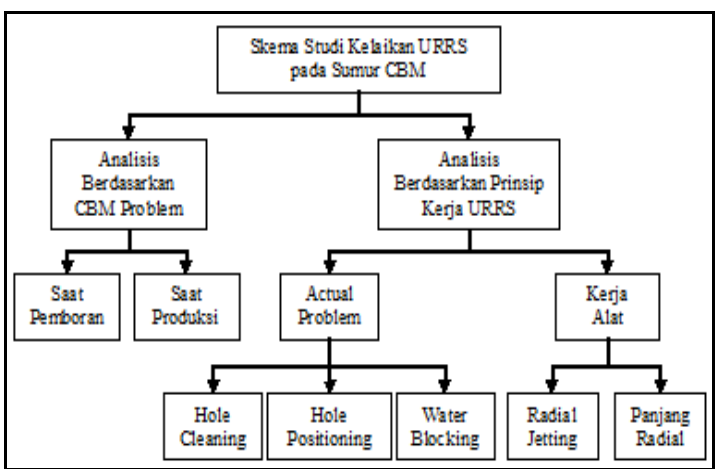

Gambar 2. Diagram Alur Studi Kelaikan RJD pada Sumur CBM

\subsection{Studi Berdasarkan Prinsip Kerja RJD \\ RJD yang hingga kini hanya} diaplikasikan pada reservoir konvensional dan tentunya memiliki beberapa catatan penting terkait dengan kerja alatnya yang khusus dan kegagalan dalam pengaplikasiaanya. Oleh karena itu dalam pengujian berdasarkan prinsip kerja RJD peneliti menurunkannya lagi kedalam dua bagian sebagai berikut.

\subsubsection{Pengujian berdasarkan kerja alat}

Diantara alat-alat khusus yang terdapat pada konfigurasi RJD tercatat ada dua alat yang perlu mendapatkan perhatian lebih terkait dengan kelaikannya jika diaplikasikan pada formasi CBM yaituradial jet dan panjang radial.

\subsubsection{Pengujian berdasarkan actual problem}

Seiring dengan RJD yang mulai masuk dalam daftar opsi pada pengembangan suatu lapangan konvensional terlebih pada 
lapangan marginal (mature field) khususnya di Indonesia sehingga memberikan referensi baru terkait dengan kegagalan kerja RJD dalam aplikasinya.

Dengan menggunakan laporan penelitian lapangan sebagai referensi terkait kegagalan RJD yang tidak berperan sebagaimana fungsinya maka peneliti mencoba melakukan rangkuman terhadap beberapa masalah yang hadir sebagai actual problem.

Kaitannya dengan aplikasi RJD untuk sumur CBM yang perlu dijawab adalah kemungkinan masalah tersebut yang akan menjadi hambatan. Adapun beberapa masalah yang dipertimbangkan berdasarkan pengamatan lapangan dari aplikasi RJD pada reservoir konvensional adalah hole cleaning akibat dari kegagalan cutting transport pada saat proses penembusan formasi sedang berlangsung, hole position yang dipengaruhi oleh ketebalan zona target dan konsistensi penembusan horizontal, serta water blocking akibat penggunaan air sebagai material dalam melakukan proses pemboran.

\subsection{Studi Berdasarkan CBM Problem}

Terdapat beberapa kegagalan yang terjadi selama proses pengembangan lapangan CBM seperti kegagalan pada saat proses pemboran CBM, pada saat melakukan stimulasi dengan hydraulic fracturing dan pada saat proses produksi ${ }^{12}$. Kegagalan yang muncul selama proses pemboran sampai pada produksi CBM pada coal rank anthracite, bituminous dan subbituminous umumnya dipengaruhi oleh:beberapa faktor penting diantaranya, in situ stress, coal rank, wellbore deviation, yang berimplikasi terhadap stabilitas lubang bor, collapse dan coal fines sehingga menurunkan produktifitas sumur CBM.

\section{Permodelan dan Sensitivitas}

Pada tahapan ini permodelan lapangan CBM dilakukan dengan menggunakan simulator yang kemudian melakukan beberapa sensitivitas sehingga diperoleh perbandingan antara lapangan yang diproduksikan dengan komplesi vertikal dan lapangan yang diproduksikan dengan komplesi Radial Jet Drilling (RJD). Data yang digunakan adalah data lapangan WS di Indonesia tepatnya pada formasi BP.

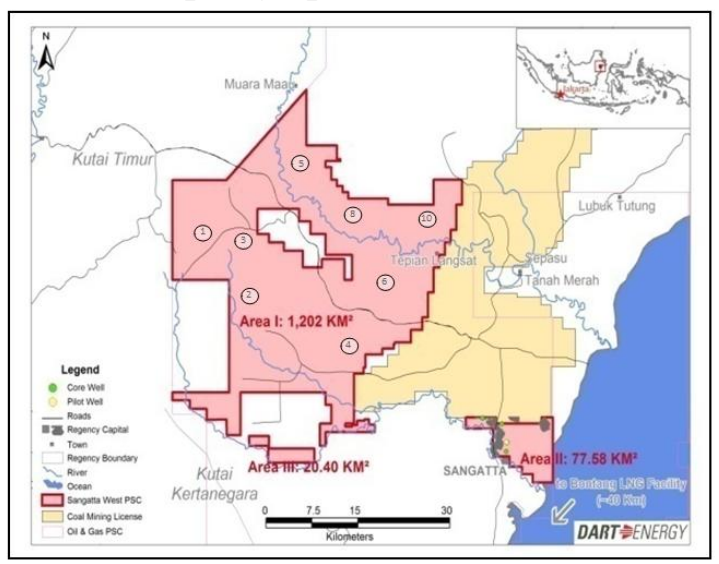

Gambar 3. Peta Lokasi Lapangan WS (dimodifikasi) $^{24}$.

Adapun properties yang digunakan sebagai berikut.

$$
\begin{aligned}
& \text { - } \mathrm{A}=160 \text { acres } \\
& \text { - } \mathrm{h}=11.811 \mathrm{ft} \\
& \text { - } \operatorname{Pr}=700 \mathrm{psi} \\
& \text { - } \mathrm{Tr}=95 \mathrm{~F} \\
& \text { - } \mathrm{Cgi}=215 \mathrm{SCF} / \text { ton } \\
& \text { ○ Moisture }=7.1 \% \\
& \circ \text { Ash }=0.9 \% \\
& \text { ○ Volatile }=39.7 \% \\
& \text { ○ } \rho_{\text {coal }}=81.159 \mathrm{lb} / \mathrm{ft}^{3} \\
& \text { - } \quad \mathrm{P}_{\mathrm{L}}=356.8 \mathrm{psi} \\
& \text { - } \mathrm{V}_{\mathrm{L}}=325 \mathrm{SCF} / \text { ton } \\
& \text { - } \mathrm{C}_{\mathrm{r}}=0.0000161 / \mathrm{psi} \\
& \text { - } \quad k_{\mathrm{frc}}=2.55 \mathrm{md} \text { (face cleat), } 2.55 \\
& \text { md (but cleat) } \\
& \text { - } \quad k_{\mathrm{mat}}=0.0001 \mathrm{md} \\
& \text { - } \phi_{\text {frc }}=0.01 \\
& \text { - } \phi_{\mathrm{mat}}=0.01 \\
& \text { - } \quad \mathrm{Sw}_{\mathrm{frc}}=0.5 \\
& \text { - } \mathrm{Sw}_{\text {mat }}=0.99 \\
& \text { - } \quad \mathrm{Int}_{\mathrm{frc}}=0.042 \mathrm{ft}
\end{aligned}
$$

Simulasi dikembangkan dengan melakukan beberapa sensitivitas pada sistem komplesi sumur dengan metode komplesi vertikal dan metoda RJD. Hal ini bertujuan 
untuk melihat efektifitas dari sistem komplesi yang disimulasikan sehingga diperoleh batasan untuk mendapatkan harga produksi yang optimum.

\subsection{Sumur Vertikal}

Sebagai base model lapangan CBM diproduksi dengan 1 (satu) sumur vertikal. Selanjutnya simulasi dilakukan dengan menambah jumlah sumur produksi yang ditempatkan secara random dengan jumlah 2, 3, 4, 5, 6, 8 dan 10 sumur. Perbandingan peningkatan laju produksi $\left(\mathrm{q}_{\mathrm{g}}\right)$ dan produksi kumulatif $\left(\mathrm{Q}_{\mathrm{g}}\right)$ selama proses simulasi dilakukan dapat dilihat pada Tabel 1.

Tabel 1. Laju Produksi $\left(\mathrm{q}_{\mathrm{g}}\right)$ dan Produksi Kumulatif

$\left(Q_{g}\right)$ Sumur Vertikal berdasarkan Penambahan Jumlah Sumur

\begin{tabular}{ccc}
\hline Jumlah Sumur & $\begin{array}{c}\text { Qg } \\
\text { (MMSCFD) }\end{array}$ & $\begin{array}{c}\text { Qg } \\
\text { (BSCF) }\end{array}$ \\
\hline $\mathbf{1}$ & 0.017 & 0.157 \\
$\mathbf{2}$ & 0.029 & 0.259 \\
$\mathbf{3}$ & 0.043 & 0.338 \\
$\mathbf{4}$ & 0.056 & 0.388 \\
$\mathbf{5}$ & 0.070 & 0.433 \\
$\mathbf{6}$ & 0.080 & 0.459 \\
$\mathbf{8}$ & 0.101 & 0.507 \\
$\mathbf{1 0}$ & 0.122 & 0.543 \\
\hline
\end{tabular}

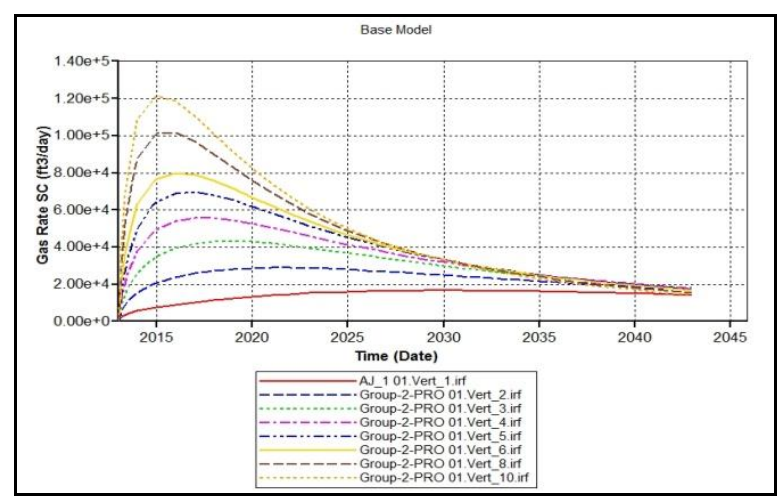

Gambar 4. Perbandingan Laju Produksi (q) Sumur Vertikal dalam MMSCFD pada Lapangan CBM Seiring dengan Penambahan Jumlah sumur.

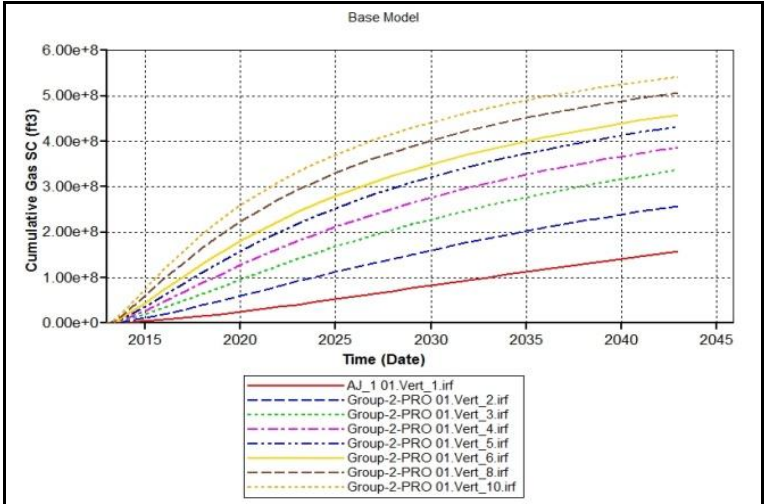

Gambar 5. Perbandingan Produksi Kumulatif (Q) Sumur Vertikal dalam BSCF pada Lapangan CBM

Seiring dengan Penambahan Jumlah sumur.

\subsection{Sumur RJD}

Pada langkah selanjutnya model kemudian disimulasikan dengan komplesi RJD dan melakukan perbandingan peningkatan laju produksi dan produksi kumulatif yang terjadi sebagai fungsi dari jumlah fase radial dan panjang radial. Fase radial yang digunakan adalah $\left(90^{\circ}, 180^{\circ}\right.$, $270^{\circ}$ dan $360^{\circ}$ ) dan panjang radial yang disensitivitas adalah 100, 150, 300, 400 dan 500 dalam satuan feet (ft). Adapun hasil yang diperoleh dapat dilihat pada Tabel 2 dan 3.

Tabel 2. Laju Produksi Gas $\left(\mathrm{q}_{\mathrm{g}}\right)$ Sumur RJD berdasarkan Penambahan Fase dan Panjang Radial dalam satuan MMSCFD.

\begin{tabular}{|l|l|l|l|l|l|}
\hline \multirow{2}{*}{ Iumlah Fase Radial } & \multicolumn{5}{|c|}{ Panjang Radial (ft) } \\
\cline { 2 - 6 } & 100 & 150 & 300 & 400 & 500 \\
\hline $1\left(90^{\circ}\right)$ & 0.029 & 0.031 & 0.042 & 0.047 & 0.052 \\
\hline $2\left(90^{\circ}, 180^{\circ}\right)$ & 0.037 & 0.040 & 0.060 & 0.071 & 0.083 \\
\hline $3\left(90^{\circ}, 180^{\circ}, 270^{\circ}\right)$ & 0.041 & 0.044 & 0.069 & 0.084 & 0.100 \\
\hline $4\left(90^{\circ}, 180^{\circ}, 270^{\circ}, 360^{\circ}\right)$ & 0.045 & 0.047 & 0.078 & 0.096 & 0.117 \\
\hline
\end{tabular}

Tabel 3. Produksi Kumulatif Gas $\left(\mathrm{Q}_{\mathrm{g}}\right)$ Sumur RJD berdasarkan Penambahan Fase dan Panjang Radial dalam satuan BSCF.

\begin{tabular}{|l|l|l|l|l|l|}
\hline \multirow{2}{*}{ Iumlah Fase Radial } & \multicolumn{5}{|c|}{ Panjang Radial (ft) } \\
\cline { 2 - 6 } & 100 & 150 & 300 & 400 & 500 \\
\hline $1\left(90^{\circ}\right)$ & 0.263 & 0.273 & 0.335 & 0.356 & 0.371 \\
\hline $2\left(90^{\circ}, 180^{\circ}\right)$ & 0.311 & 0.322 & 0.402 & 0.432 & 0.458 \\
\hline $3\left(90^{\circ}, 180^{\circ}, 270^{\circ}\right)$ & 0.331 & 0.341 & 0.425 & 0.457 & 0.486 \\
\hline $4\left(90^{\circ}, 180^{\circ}, 270^{\circ}, 360^{\circ}\right)$ & 0.347 & 0.356 & 0.445 & 0.480 & 0.512 \\
\hline
\end{tabular}


Pengamatan dilakukan untuk melihat variabel yang memiliki pengaruh lebih dominan terhadap produksi sumur RJD antara panjang radial dan fase radial. Sebagaimana yang dapat diamati melalui grafik pada Gambar 8 sampai Gambar 11.

Dalam hubungannya dengan laju produksi dan produksi kumulatif diperoleh hasil bahwa penambahan panjang radial tiap 50-100 ft memiliki pengaruh lebih dominan dibandingkan dengan penambahan fase radial tiap 1 fase. Seperti yang diperlihatkan pada Gambar 8 dimana kenaikan laju produksi yang terjadi lebih signifikan dibandingkan profil produksi yang diperlihatkan pada Gambar 9.

Pengamatan serupa yang dilakukan pada profil produksi kumulatif dan diperoleh hasil yang berbanding lurus, bahwa panjang radial memiliki pengaruh lebih dominan terhadap peningkatan produksi kumulatif dibandingkan dengan jumlah radial.

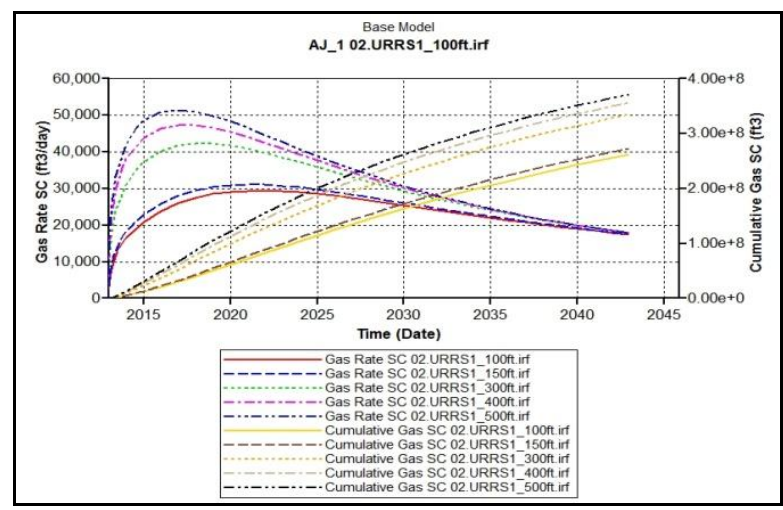

Gambar 6. Perbandingan Laju Produksi Gas $\left(\mathrm{q}_{\mathrm{g}}\right)$ dan Produksi Kumulatif Gas $\left(\mathrm{Q}_{\mathrm{g}}\right)$ Sumur RJD dengan Jumlah Radial 1 (satu) Fase $\left(90^{\circ}\right)$ yang disensitifitas Terhadap Panjang Radial pada 100, 150, 300, 400 dan $500 \mathrm{ft}$.

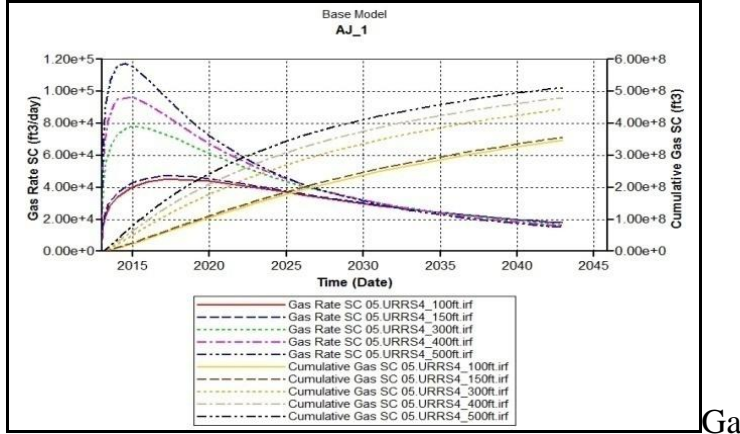

mbar 7. Perbandingan Laju Produksi Gas $\left(\mathrm{q}_{\mathrm{g}}\right)$ dan Produksi Kumulatif Gas $\left(\mathrm{Q}_{\mathrm{g}}\right)$ Sumur RJD dengan Jumlah Radial 4 (empat) Fase $\left(90^{\circ}, 180^{\circ}, 270^{\circ}, 360^{\circ}\right)$ yang disensitifitas Terhadap Panjang Radial pada 100, 150, 300, 400 dan $500 \mathrm{ft}$.

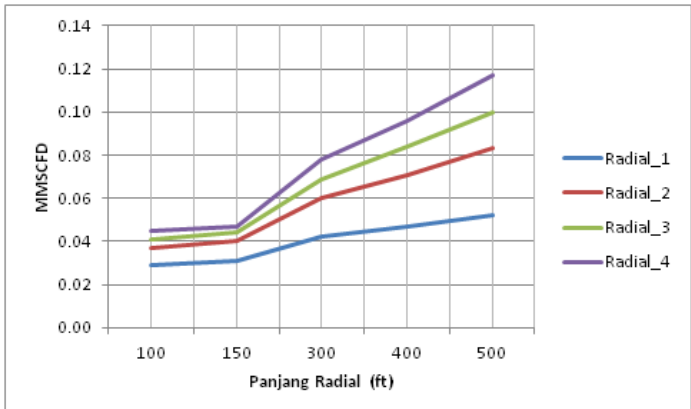

Gambar 8. Profil Laju Produksi Pada Masing-masing Fase Radial yang Disensitivitas Terhadap Panjang Radial Pada Sistem Komplesi RJD.

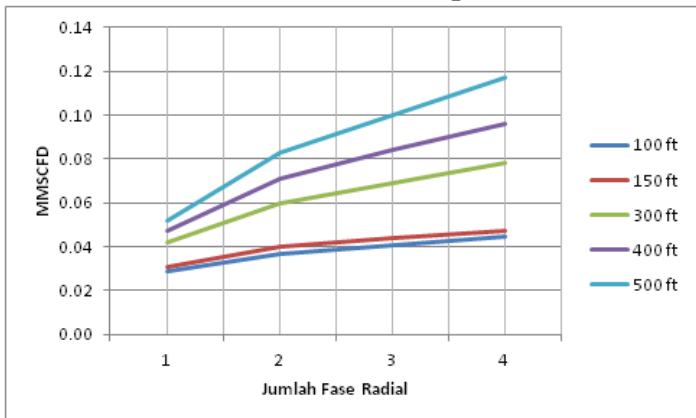

Gambar 9. Profil Laju Produksi Pada Masing-masing Panjang Radial yang Disensitivitas Terhadap Fase Radial Pada Sistem Komplesi RJD. 


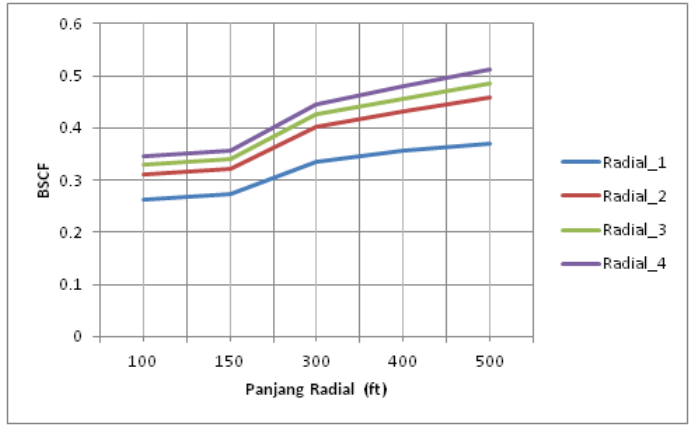

Gambar 10. Profil Produksi Kumulatif Masingmasing Fase Radial yang Disensitivitas Terhadap

Panjang Radial Pada Sistem Komplesi RJD.

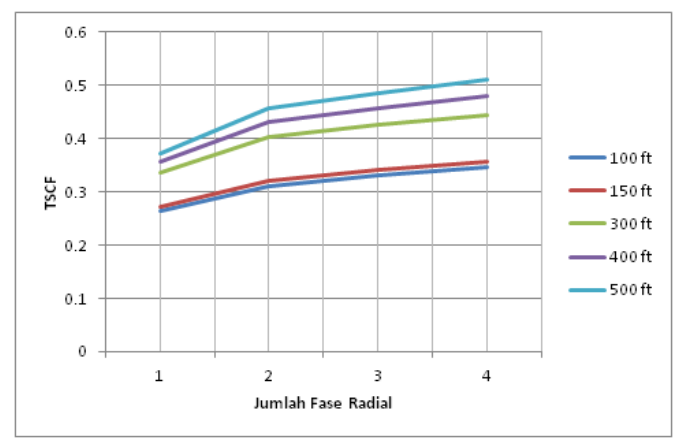

Gambar 11. Profil Produksi Kumulatif Pada Masingmasing Panjang Radial yang Disensitivitas Terhadap

Fase Radial Pada Sistem Komplesi RJD.

\subsection{Perbandingan Sumur Vertikal dan RJD}

Setelah melakukan pengamatan profil produksi pada masing-masing sistem komplesi yang disimulasikan dengan beberapa sensitivitas. Maka pada langkah selanjutnya dilakukan perbandingan antara kedua sistem komplesi tersebut untuk melihat efektifitas antara penambahan fase radial dan panjang radial pada sistem RJD atau sumur vertikal dengan menambah jumlah sumur berdasarkan laju produksi dan produksi kumulatif gas sebagaimana yang dapat dilihat pada Gambar 12.

Perbandingan laju produksi gas $\left(\mathrm{q}_{\mathrm{g}}\right)$ dan produksi kumulatif gas $\left(\mathrm{Q}_{\mathrm{g}}\right)$ sumur antara sistem komplesi vertikal yang disensitivitas dengan penambahan jumlah sumur dan sistem komplesi RJD yang disensitivitas pada fase dan panjang radial memperlihatkan angka maksimum terjadi pada lapangan yang diproduksi dengan 10 sumur vertikal dibandingkan lapangan yang diproduksi dengan sistem komplesi RJD dengan jumlah radial 4 fase $\left(90^{\circ}, 180^{\circ}, 270^{\circ}\right.$, $360^{\circ}$ ) dan dengan panjang yang maksimum.

Efektifitas dari kedua sistem komplesi yang dilakukan dapat dilihat secara detail melalu gradasi berdasarkan besaran laju produksi dan produksi kumulatif yang terbentuk seperti yang terlihat pada Tabel 4 .

Tabel 4. Pengurutan Hasil Perbandingan Laju Produksi Gas dan Produksi Kumulatif Gas Berdasarkan Sistem Komplesi yang Disensitivitas.

\begin{tabular}{|c|c|c|c|}
\hline No & Komplesi & $\begin{array}{c}\text { Qg } \\
\text { (MMSCFD) }\end{array}$ & $\begin{array}{c}\mathrm{Qg} \\
\text { (BSCF) }\end{array}$ \\
\hline 1 & Vertikal 1 Sumur & 0.017 & 0.157 \\
\hline 2 & Vertikal 2 Sumur & 0.029 & 0.259 \\
\hline 3 & $\begin{array}{l}\text { RJD } 1 \text { Fase Radial, } \\
100 \mathrm{ft}\end{array}$ & 0.029 & 0.263 \\
\hline 4 & $\begin{array}{l}\text { RJD } 1 \text { Fase Radial, } \\
150 \mathrm{ft}\end{array}$ & 0.031 & 0.273 \\
\hline 5 & $\begin{array}{l}\text { RJD } 2 \text { Fase Radial, } \\
100 \mathrm{ft}\end{array}$ & 0.037 & 0.311 \\
\hline 6 & $\begin{array}{l}\text { RJD } 2 \text { Fase Radial, } \\
150 \mathrm{ft}\end{array}$ & 0.040 & 0.322 \\
\hline 7 & $\begin{array}{l}\text { RJD } 3 \text { Fase Radial, } \\
100 \mathrm{ft}\end{array}$ & 0.041 & 0.331 \\
\hline 8 & $\begin{array}{l}\text { RJD } 1 \text { Fase Radial, } \\
300 \mathrm{ft}\end{array}$ & 0.042 & 0.335 \\
\hline 9 & Vertikal 3 Sumur & 0.043 & 0.338 \\
\hline 10 & $\begin{array}{l}\text { RJD } 3 \text { Fase Radial, } \\
150 \mathrm{ft}\end{array}$ & 0.044 & 0.341 \\
\hline 11 & $\begin{array}{l}\text { RJD } 4 \text { Fase Radial, } \\
100 \mathrm{ft}\end{array}$ & 0.045 & 0.347 \\
\hline 12 & $\begin{array}{l}\text { RJD } 1 \text { Fase Radial, } \\
400 \mathrm{ft}\end{array}$ & 0.047 & 0.356 \\
\hline 13 & $\begin{array}{l}\text { RJD } 4 \text { Fase Radial, } \\
150 \mathrm{ft}\end{array}$ & 0.047 & 0.356 \\
\hline 14 & $\begin{array}{l}\text { RJD } 1 \text { Fase Radial, } \\
500 \mathrm{ft}\end{array}$ & 0.052 & 0.371 \\
\hline 15 & Vertikal 4 Sumur & 0.056 & 0.388 \\
\hline 16 & $\begin{array}{l}\text { RJD } 2 \text { Fase Radial, } \\
300 \mathrm{ft}\end{array}$ & 0.060 & 0.402 \\
\hline 17 & $\begin{array}{l}\text { RJD } 3 \text { Fase Radial, } \\
300 \mathrm{ft}\end{array}$ & 0.069 & 0.425 \\
\hline 18 & $\begin{array}{l}\text { RJD } 2 \text { Fase Radial, } \\
400 \mathrm{ft}\end{array}$ & 0.071 & 0.432 \\
\hline 19 & Vertikal 5 Sumur & 0.070 & 0.433 \\
\hline 20 & $\begin{array}{l}\text { RJD } 4 \text { Fase Radial, } \\
300 \mathrm{ft}\end{array}$ & 0.078 & 0.445 \\
\hline 21 & $\begin{array}{l}\text { RJD } 3 \text { Fase Radial, } \\
400 \mathrm{ft}\end{array}$ & 0.084 & 0.457 \\
\hline 22 & RJD 2 Fase Radial, & 0.083 & 0.458 \\
\hline
\end{tabular}




\begin{tabular}{llrr}
\hline & 500 ft & & \\
$\mathbf{2 3}$ & Vertikal 6 Sumur & 0.080 & 0.459 \\
$\mathbf{2 4}$ & $\begin{array}{l}\text { RJD 4 Fase Radial, } \\
\text { 400 ft }\end{array}$ & 0.096 & 0.480 \\
$\mathbf{2 5}$ & $\begin{array}{l}\text { RJD 3 Fase Radial, } \\
\end{array}$ & 0.100 & 0.486 \\
$\mathbf{2 6}$ & 500 ft & 0.101 & 0.507 \\
$\mathbf{2 7}$ & $\begin{array}{l}\text { RJD 4 Fase Radial, } \\
\text { 500 ft }\end{array}$ & 0.117 & 0512 \\
$\mathbf{2 8}$ & Vertikal 10 Sumur & 0.122 & 0.543 \\
\hline & Dari gradasi & yang & dilakukan
\end{tabular}
sebagaimana yang terlihat pada Tabel 4 diperoleh hasil yang secara umum menjelaskan bahwa sistem RJD dengan panjang radial maksimum mampu memberikan hasil yang lebih baik dibanding lapangan CBM dengan sumur vertikal.

Selain itu dari tabel dan gambar yang sama juga dapat diamati bahwa penambahan jumlah radial yang tidak di imbangi dengan penambahan panjang radial pada sistem RJD tidak memberikan hasil yang signifikan jika dibandingkan dengan sumur vertikal yang diperbanyak jumlahnya. Sehingga dapat dikatakan bahwa penambahan jumlah radial pada sistem RJD akan mendapatkan hasil maksimum jika berbanding lurus dengan penambahan panjang radial.

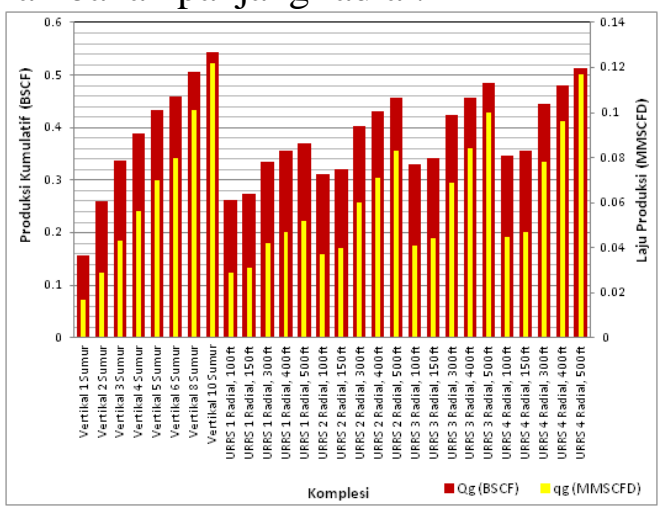

Gambar 12. Perbandingan Laju Produksi Gas $\left(\mathrm{q}_{\mathrm{g}}\right)$ pengujian kelaikan RJD pada formasi CBM sudah pasti harus mempertimbangkan masalah jetting yang memungkinkan terjadinya formasi runtuh.

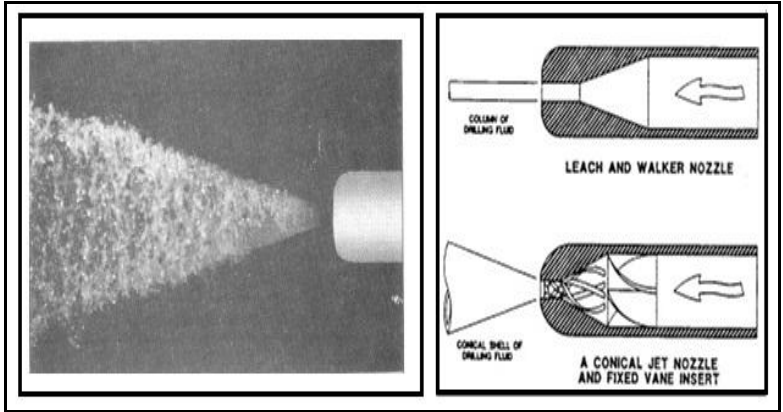

Gambar 13. Skema Sistem Jetting pada RJD

Pada kasus ini sebuah penelitian oleh Martin (1991) melalui disertasinya yang berjudul The Study of High Pressure Water Jet Assisted Cutting of Coal Samples in The Laboratory dimana dalam percobaannya melakukan pengujian pada 2 (dua) jenis batubara anthracit dan bituminous untuk menghitung penetrasi yang terjadi melalui sistim water jetting.

Ada dua faktor penentu terkait dengan panjang penetrasi yang terjadi pada sampel batubara melalui sistim jetting iaitu pressure jet dan velocity jet. Kedua faktor ini kemudian diukur melalui beberapa kali percobaan yang dilakukan dengan meningkatkan tekanan jet pada laju lintasan (velocity) jet tertentu untuk mengetahui efek penetrasi dari tiap percobaan yang dilakukan sehingga diperoleh tabulasi sebagai berikut.

Tabel 5. Laju Penetrasi yang Terjadi Berdasarkan Jet Pressure dan Jet Velocity ${ }^{10}$. dalam MMSCFD dan Produksi Kumulatif Gas $\left(\mathrm{Q}_{2}\right.$ dalam BSCF Berdasarkan Sistem Komplesi yang ${ }^{5}$ Speed Disensitivitas.

\section{Pembahasan}

\section{Sistem Jetting}

Penembusan formasi dengan jetting yang dilakukan oleh RJD memungkinkan terjadinya formasi damage pada struktur batubara yang dikenal lebih rapuh (brittle). Oleh karena itu dalam

\begin{tabular}{|c|c|c|c|c|c|c|c|c|}
\hline \multirow{2}{*}{$\begin{array}{c}\text { Speed } \\
(\mathrm{m} / \mathbf{s})\end{array}$} & \multicolumn{4}{|c|}{ Anthracite Coal } & \multicolumn{4}{|c|}{ Erin ( bituminous) Coal } \\
\hline & $\begin{array}{c}35 \\
(\mathrm{MPa})\end{array}$ & $\begin{array}{c}52.5 \\
(\mathrm{MPa})\end{array}$ & $\begin{array}{c}70 \\
(\mathrm{MPa})\end{array}$ & $\begin{array}{c}105 \\
(\mathrm{MPa})\end{array}$ & $\begin{array}{c}35 \\
(\mathrm{MPa})\end{array}$ & $\begin{array}{c}52.5 \\
(\mathrm{MPa})\end{array}$ & $\begin{array}{c}70 \\
(\mathrm{MPa})\end{array}$ & $\begin{array}{c}105 \\
(\mathrm{MPa})\end{array}$ \\
\hline 0.24 & 11.1 & 18.0 & 37.6 & 51.4 & 15.9 & 23.4 & 42.5 & 76.0 \\
\hline 0.64 & 9.2 & 14.3 & 26.6 & 40.0 & 11.9 & 16.3 & 33.9 & 51.1 \\
\hline 0.90 & 8.4 & 11.1 & 23.0 & 26.7 & 11.2 & 15.5 & 28.0 & 38.1 \\
\hline 1.10 & 6.5 & 10.5 & 21.3 & 22.1 & 10.7 & 10.7 & 28.2 & 26.4 \\
\hline
\end{tabular}

Dari tabulasi diatas dapat dilihat bahwa pressure memiliki pengaruh lebih dominan terhadap penetrasi dibandingkan velocity. 
Namun pentrasi terbaik terjadi pada percobaan dengan velocity yang paling rendah $(0.24 \mathrm{~m} / \mathrm{s})$ sehingga dapat dikatakan bahwa hubungan antara pressure terhadap laju penetrasi bukanlah faktor independen melainkan memiliki relasi dengan velocity rendah seiring dengan penambahan pressure.

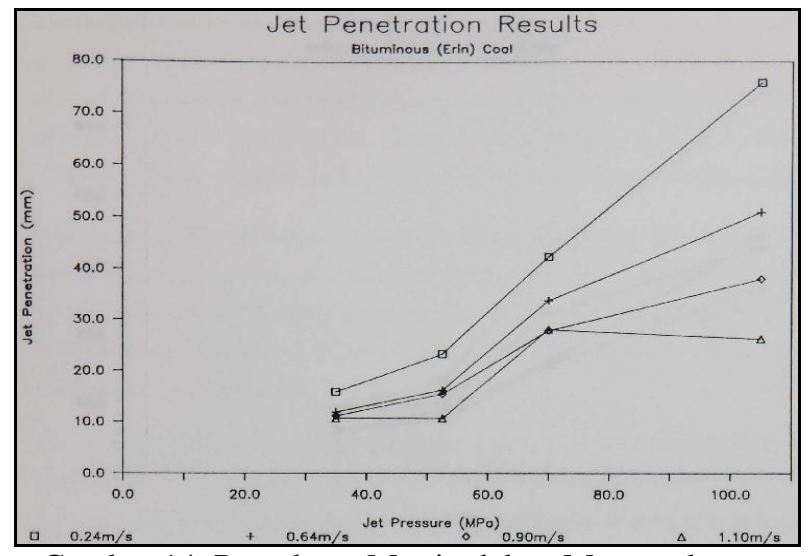

Gambar 14. Percobaan Martin dalam Menentukan Laju Penetrasi pada Batubara Bituminous ${ }^{10}$.

Percobaan berlanjut untuk melihat laju penetrasi yang terjadi pada cleat anthracit dengan experimental faktor yang sama pada pengujian sebelumnya dan diperoleh hasil sebagai berikut.

Tabel 6. Pengukuran Laju Pentrasi pada Cleat Anthracit $^{10}$. iaitu penetrasi terbaik terjadi saat velocity

sistim jetting yang terdapat pada RJD dapat diaplikasikan pada formasi CBM dengan mengatur terlebih dahulu besaran tekanan dan velocity jetting yang digunakan untuk mendapatkan laju penetrasi yang terbaik. Lapangan telitian yang merupakan jenis coal rank Bituminous.

\section{Panjang Radial}

Pada proses pensimulasian dan sensitivitas yang dilakukan pada bab sebelumnya memperlihatkan bahwa panjang radial dan jumlah radial merupakan fungsi dari produksi sumur RJD meski dalam beberapa sensitivitas yang dilakukan menunjukkan bahwa panjang radial menjadi variabel yang lebih dominan dalam mempengaruhi produksi gas methan dibanding jumlah radial pada sumur RJD. Sehingga dapat dikatakan bahwa semakin panjang radial dalam menembus formasi maka semakin besar produksi yang diberikan oleh sumur RJD.

Umumnya panjang radial yang dijangkau dalam penggunaan RJD pada lapangan konvensional ialah $8 \mathrm{~s} / \mathrm{d} 46 \mathrm{~m}$ (25 $-150 \mathrm{ft})^{5}$. Walaupun terdapat referensi yang menyebutkan bahwa saat ini rekor panjang radial yang pernah ditempuh oleh RJD sepanjang $200 \mathrm{~m}$ (656 ft). Kondisi ini pastinya memiliki konsekuensi yang tidak medah dari segi teknis alat dan kekerasan

\begin{tabular}{|c|c|c|c|c|c|c|c|c|}
\hline \multirow{2}{*}{$\begin{array}{c}\text { Speed } \\
(\mathbf{m} / \mathbf{s})\end{array}$} & \multicolumn{4}{|c|}{ Cleat Parallel } & \multicolumn{4}{|c|}{ Cleat Perpendicular } \\
\hline & $\begin{array}{c}35 \\
(\mathrm{MPa})\end{array}$ & $\begin{array}{c}52.5 \\
(\mathrm{MPa})\end{array}$ & $\begin{array}{c}70 \\
(\mathrm{MPa})\end{array}$ & $\begin{array}{c}105 \\
\text { (MPa) }\end{array}$ & $\begin{array}{c}35 \\
\text { (MPa) }\end{array}$ & $\begin{array}{c}52.5 \\
(\mathrm{MPa})\end{array}$ & $\begin{array}{c}70 \\
(\mathrm{MPa})\end{array}$ & \\
\hline 0.24 & 11.1 & 18.0 & 37.6 & 51.4 & 8.9 & 13.5 & 31.8 & \\
\hline 0.64 & 9.2 & 14.3 & 26.6 & 40.0 & 9.6 & 10.0 & 23.7 & \\
\hline 0.90 & 8.4 & 11.1 & 23.0 & 26.7 & 5.8 & 9.0 & 16.4 & \\
\hline 1.10 & 6.5 & 10.5 & 21.3 & 22.1 & 6.2 & 7.7 & 15.8 & 2 \\
\hline
\end{tabular}

Pengujian laju penetrasi yang terbentuk pada face cleat dan butt cleat anthracit sebagaimana yang diperlihatkan pada tabel diatas tidaklah memperlihatkan perbedaan yang signifikan. Sehingga dapat dikatakan bahwa laju penetrasi terbaik pada cleat batubara pada saat jetting dilakukan sama dengan percobaan sebelumnya.

Berdasarkan beberapa percobaan tersebut diatas dapat disimpulkan bahwa
10 5ormasi yang ditembus maka range yang (MPlìmunculkan dalam sensitivitas pada 35.6 panjang radial RJD adalah $100-500 \mathrm{ft}$. 34.8 Umumnya panjang radial yang dijangkau dalam penggunaan alat dengan sistem serupa dengan RJD atau yang dikenal dengan Ultrashort Radius Radial Sistem (URRS) pada lapangan konvensional ialah 8 s/d $46 \mathrm{~m}(25-150 \mathrm{ft})$. Walaupun terdapat referensi yang menyebutkan bahwa saat ini rekor panjang radial yang pernah ditempuh oleh URRS sepanjang $200 \mathrm{~m}$ (656 ft). Kondisi ini pastinya memiliki konsekuensi yang tidak mudah dari segi teknis alat dan kekerasan formasi yang ditembus maka 
range yang dimunculkan dalam sensitivitas pada panjang radial RJD adalah $100-500 \mathrm{ft}$ mengingat penembusan dilakukan dengan menggunakan sistem jetting sementara URRS diatas menggunakan bit konvensional sehingga adanya weight on bit (WOB) pada rangakain drill string menyebabkan rangkaian lebih berat dan berimplikasi pada hole positioning.

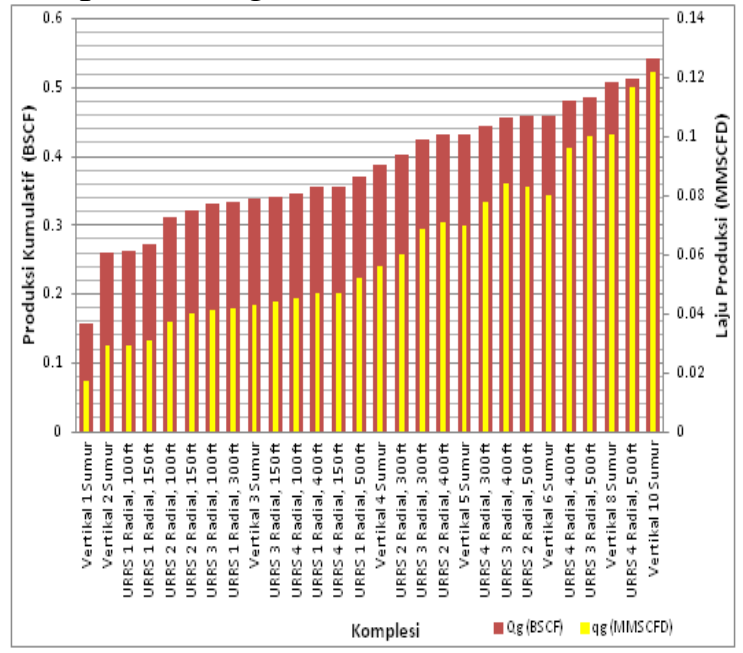

Gambar 15. Pengurutan Hasil Perbandingan Laju

Produksi Gas $\left(\mathrm{q}_{\mathrm{g}}\right)$ dalam MMSCFD dan Produksi

Kumulatif Gas $\left(\mathrm{Q}_{\mathrm{g}}\right)$ dalam BSCF Berdasarkan Sistem Komplesi yang Disensitivitas

\section{Wellbore Stability}

Stabilitas lubang bor (wellbore stability) dipengaruhi oleh tegangan insitu dan kekerasan batubara. Sehingga dapat dipastikan bahwa wellbore stability akan memburuk seiring dengan kedalaman formasi terlebih pada coal rank yang rendah. Pengujian yang dilakukan Palmer memperlihatkan masalah wellbore stability yang muncul pada lvb, mvb dan hvAb saat proses pemboran berlangsung.

Catatan ini akan menjadi sangat penting sebagai parameter screaning dalam penentuan jenis batubara yang dianggap laik ditembus oleh RJD meski laporan tersebut tidak dapat di genaralisir. Potensi gas CBM terbesar yang berada pada jenis batubara bituminous yang dimulai dari high volatile $\mathrm{C}$ (hvCb) sampai dengan low volatile (lvb) akan tetap menjadi pertimbangan untuk mendapatkan hasil yang maksimum dalam memproduksikan gas metan dari formasi batubara. Oleh karena itu penentuan rank batubara yang dianggap laik untuk mengaplikasikan RJD adalah low volatile bituminous s/d medium volatile bituminous.

\section{Dewatering}

Memproduksi dan membuang air mengasumsikan perbedaan yang sangat penting dalam projek CBM dibandingkan dengan operasi minyak dan gas konvensional. Memproduksi air pada awal ekstraksi gas CBM menjadi hal yang umum dan hampir dijumpai pada setiap pengembangan lapangan $\mathrm{CBM}$ dan proses ini dikenal dengan dewatering process.

Profil produksi air sumur CBM (dewatering process) memperlihatkan puncaknya setelah satu tahun dan kemudian menurun selama umur sisa cadangan terkecuali jika sumur berada di pinggir pola, atau formasi batubara memiliki permeabilitas tinggi dan terhubung dengan aquifer atau air meteoric (Rudy, 2005). Untuk mempercepat proses dewatering biasanya sumur CBM difasilitasi dengan artificial lift berupa PCP, SRP ataupun ESP yang berfungsi untuk membantu pengangkatan air kepermukaan.

Dalam kaitannya dengan masalah water blocking yang biasa disebabkan oleh penggunaan material air dalam menembus formasi pada aplikasi RJD dapat diabaikan mengingat beberapa mekanisme dewatering sebagaimana yang disebutkan diatas. Sehingga dengan kata lain bahwa water blocking dalam aplikasi RJD pada sumur CBM dapat diabaikan.

\section{Flexible Sand Barrier}

Slotted liner yang lentur telah dikembangkan untuk dipergunakan sebagaimana fungsi sebuah liner dan untuk menunjang perforasi. Slotted liner ini adalah pipa logam yang dibentuk seperti pilin. Secara lugas menyerupai saluran logam lentur yang konvensional. FSB (Flexible 
Sand Barier) dapat dipompakan keluar ujung pemotongan drillstring 11/4 inch (32 $\mathrm{mm}$ ) dan dikaitkan pada formasi dengan pengembangan serangkaian durinya yang seperti tombak. Drillstring kemudian dapat ditarik kembali membiarkan FSB terkait pada tempatnya.

Sebagai alternatif, FSB dapat dipompakan turun menuju drillstring untuk menjalankan fungsinya didalam lubang perforasi sehingga pencegahan terproduksikannya coal fines kepermukaan pada sumur CBM semakin baik. Sedangkan metoda pemasangan liner sendiri pada sumur CBM menjadi hal yang umum sebagai antisipasi dari masalah coal fines yang kerap hadir saat gas metan mulai diproduksikan dari formasi CBM. Oleh karena itu keberadaan FSB pada konfigurasi RJD sebagai sebuah alternatif komplesi pada rangkaian horizontal dapat diandalkan untuk meminamilisir terproduksikannya coal fines pada aplikasi RJD di lapangan CBM.

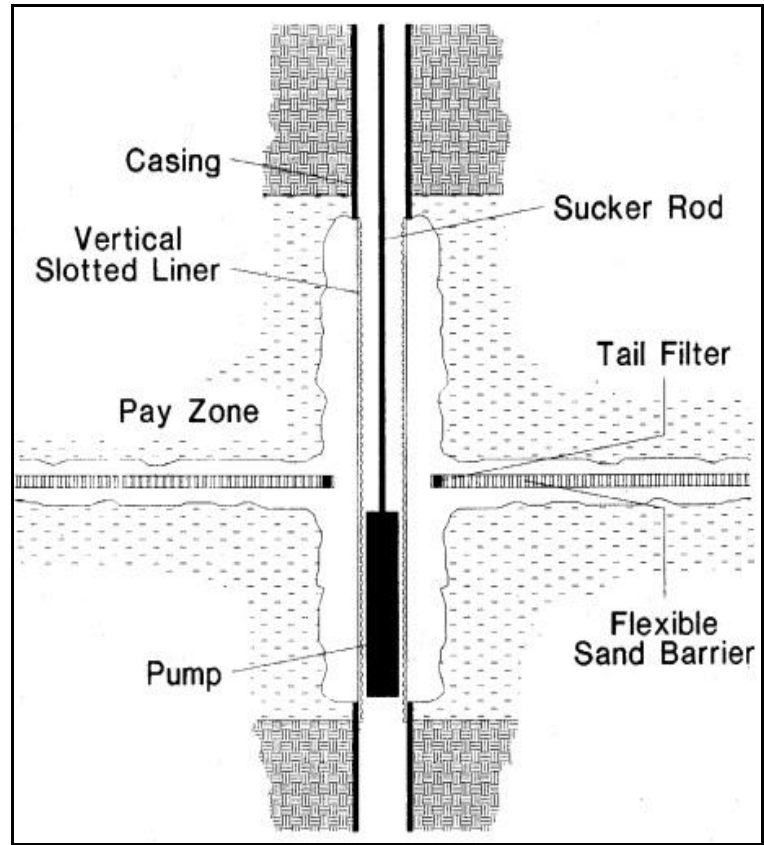

Gambar 16. Sistem Komplesi RJD dengan Fasilitas Flexible Sand Barrier ${ }^{6}$.

\section{Control While Drilling}

Saat rangkaian RJD menembus formasi secara horizontal seringkali terjadi penyimpangan (naik/turun) yang menyebabkan kerugian karena rangkaian menembus zona yang tidak di inginkan seperti aquifer. Pada kasus ini panjang lintasan target horizontal dan kekerasan formasi menjadi fungsi terjadinya pergerakan rangkaian naik/turun seperti yang biasanya dialami RJD pada lapangan konvensional.

Kelemahan yang terdapat pada konfigurasi RJD ini telah diamati dan mendapatkan perhatian khusus iaitu pengontrolan selama proses penetrasi berlangsung. Setidaknya tercatat beberapa makalah yang menyinggung masalah tersebut sejak 1990 an $^{6}$. Sebuah mekanisme yang terdapat pada konfigurasi RJD dengan fungsi sebagai pengontrol selama proses penetrasi berlangsung.

Untuk mendapatkan pengontrolan saluran bagi radial-radial yang melebihi 30 feet $(10 \mathrm{~m})$, sistem pengontrolan selama berlangsungnya pengeboran telah dikembangkan dan menjalani ujicoba lapangan. Kontrol secara otomatis didapatkan dari sinyal pancaran fluida (arah pancaran kesamping secara tegak lurus pada poros bor). Sensor gaya berat internal di dalam kepala bor memberikan petujuk saat naik/turun yang sebenarnya.

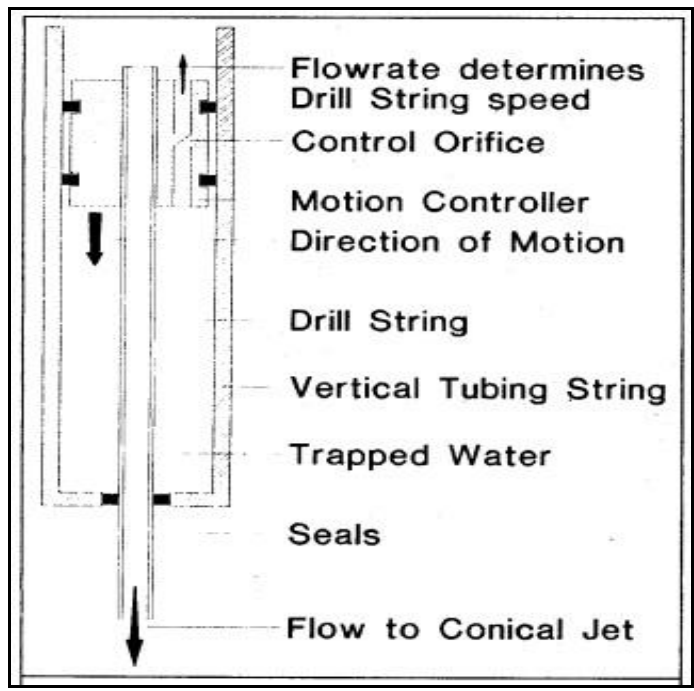

Gambar 17. Mekanisme Pengontrolan Pentrasi Selama Pemboran ${ }^{6}$. 
Dari pembahasan masing-masing pengujian diatas sebagaimana yang diusulkan dalam studi kelaikan RJD pada lapangan CBM maka diperoleh parameter yang dapat digunakan sebagai screaning dalam menentukan lapangan yang dianggap laik mengaplikasikan sistem komplesi RJD beserta spesifikasi alat yang harus terdapat pada konfigurasi RJD itu sendiri seperti yang terlihap pada gambar berikut.

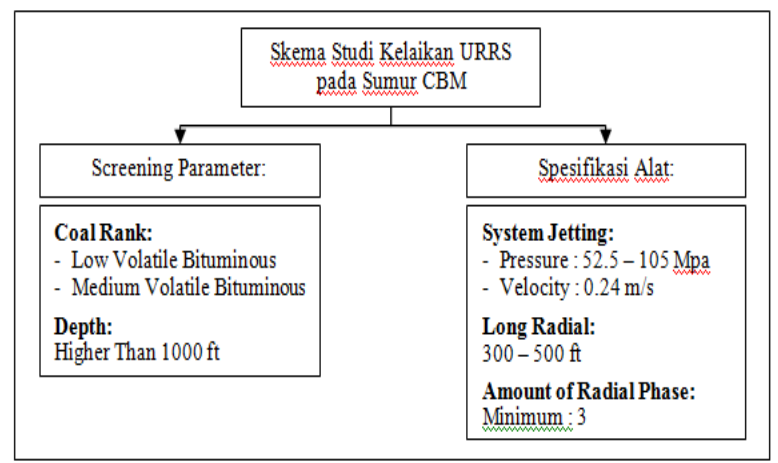

Gambar 18. Diagram Alur Studi Kelaikan RJD pada Sumur CBM

\section{Kesimpulan}

Berdasarkan studi kelaikan Radial Jet Drilling pada lapangan CBM dengan menggunakan parameter prinsip alat dan karakteristik formasi CBM sebagaimana yang telah dibahas pada bab sebelumnya, maka dapat ditarik beberapa kesimpulan sebagai berikut.

1. Radial Jet Drilling dapat diaplikasikan pada sumur CBM tepatnya pada lapangan WS.

2. Efektifitas RJD dapat dicapai pada jumlah fase minimum 3 (tiga), dengan jarak masing-masing fase $90^{\circ}$ dan dengan panjang radial masing-masing fase $300 \mathrm{ft}-500 \mathrm{ft}$

3. Lapangan CBM yang dianggap laik mengaplikasikan RJD ialah pada kelas batubara (coal rank) low volatile bituminous (lvb) s/d medium volatile bituminous (mvb) dan pada kedalaman lebih besar dari 1,000 ft.

\section{Daftar Referensi}

[1] Abdassah, D. (2010) : Unconventional Hydrocarbon Recovery, Sosialisasi Aktivitas Operasional Gas Metana Batubara (CBM)Jurusan Teknik Perminyakan ITB, Jakarta.

[2] Abdassah, D. (2010) : Defenisi dan Elaborasi Coalbed Methane, Sosialisasi Aktivitas Operasional Gas Metana Batubara (CBM) Jurusan Teknik Perminyakan ITB, Jakarta.

[3] Department of Energy (DOE), (September 2003) :Multi-Seam Well Completion Technology "Implications for Powder River Basin Coalbed Methane Production", Contract No. DOE/NETL/1193, U.S.

[4] Dickinson, W., dan Dickinson, R.W. (1985) : Horizontal Radial Drilling System, Society of Petroleum Engineers, 13949.

[5] Dickinson, W., Dykstra, H., Nordlund, R., dan Dickinson, R.W. (1993) : Coiled-Tubing Radials Placed by Water-Jet Drilling "Filed Results, Theory, and Practice", Society of Petroleum Engineers, 26348.

[6] Dickinson, W., Anderson, R.R., dan Dickinson, R.W. (1989) : The Ultrashort-Radius Radial System, Society of Petroleum Engineers Drilling Engineering, 247-254.

[7] Ginting, L.B. (2009) :Studi Potensi Coalbed Methane (CBM) Berdasarkan Karakteristik Batubara di Lapanagan Rambutan Cekungan Sumatera Selatan, Tesis Program MasterTeknik Rekayasa Pertambangan, Insitut Teknologi Bandung.

[8] Holditch, S.A., (1990) : Completion Methods in Coal Seam Reservoir, Society of Petroleum Engineers, 20670.

[9] Lightfoot, J. (2007) : Drilling Sideways in Coal Seams (Development of New "Fit for Purpose" Technology to Oprimize CBM Horizontal Drilling), International Colbed Methane Symposium, 0707 Tuscaloosa, Alabama.

[10] Martin, J. (1991) : The Study of High Pressure Water Jet Assisted Cutting of Coal samples in The Laboratory, Thesis of Doctor Program, University of Newcastle upon Tyne.

[11] Mutalik, P.N., dan Magness, W.D. (2006) : Production Data Analysis of Horizontal CBM Wells in Arkoma Basin, Society of Petroleum Engineers, 103206. 
[12] Palmer, I., Moschovidis, Z., dan Cameron, J. (2005) : Coal Failure and Consequences for Coalbed Methane Wells, Society of Petroleum Engineering, 96872.

[13] Partowidagdo, W. (2009) :Migas dan Energi di Indonesia "Permasalahan dan Analisis Kebijakan", Bandung.

[14] Ramaswamy, S. (2007) :Selection of Best Drilling, Completion and Stimulation Methods for Coalbed Methane, Thesis of Master Program, Texas A\&M University.

[15]Rhesa, R. (2008) :Studi Pengembangan Lapangan Coalbed Methane ' $X$ ' di Daerah Sumatera Selatan, Tesis Program MasterTeknik Perminyakan, Insitut Teknologi Bandung.

[16] Rogers, R.E. (1994) :Coalbed Methane Principles and Practice, Prentice Hall Petroleum Engineering Series, Mississippi State University.

[17]Rubiandini, R.R. (2010) :Rancangan Teknik Pemboran dan Komplesi, Program Studi Teknik Perminyakan, Insitut Teknologi Bandung.

[18] Stach, E., Mackowsky, M.TH., Teichmuller, M., Taylor, G.H., Chandra, D., dan Teichmuller, R. (1975) : Coal Petrology, Gebruder Borntraeger, Berlin-Stutgart.

[19] Sumaryanto. (2011) :Perencanaan Perekahan Hidraulik Muti Lapisan Reservoir CBM dengan Teknik Limited Entry, Tesis Program MasterTeknik Perminyakan, Insitut Teknologi Bandung.

[20] Situs resmi Kementrian Energi Sumberdaya Mineral RI, www.esdm.go.id

[21] Utomo, M.I.P. (2009) :Studi Kasus Evaluasi Radial Jet Drilling di Lapangan X, Tugas Akhir Program Sarjana Teknik Perminyakan, Istitut Teknologi Bandung.

[22] http://www.earthenergyreserves.com

[23] http://www.worldcoal.org/coal/coal-seammethane/coal-bed-methane/

[24] www.google.com 